Federal Reserve Bank of Dallas

Globalization and Monetary Policy Institute

Working Paper No. 174

http:// www.dallasfed.org/ assets/ documents/ institute/ wpapers/2014/ 0174.pdf

\title{
Inflation Targeting and the Anchoring of Inflation Expectations: Cross-country Evidence from Consensus Forecasts ${ }^{*}$
}

\author{
J. Scott Davis \\ Federal Reserve Bank of Dallas
}

April 2014

\begin{abstract}
Using survey data of inflation expectations across a 36 developed and developing countries, this paper examines whether the adoption of inflation targeting has helped to anchor inflation expectations. We examine the response of inflation expectations following a shock to inflation, inflation expectations, and oil prices. For the 13 countries that adopted inflation targeting midway through the time period used in this study, there is a significant difference in the responses between the earlier and the later subperiods. A shock leads to a positive, significant, and persistent increase inflation expectations in the earlier, pre-targeting subperiod, but the same response is much less significant and persistent in the later, posttargeting subperiod. For the control group of 23 countries that did not adopt inflation targeting during this time period, there is no difference between responses in the earlier and the later sub-periods.
\end{abstract}

JEL codes: D 80, E31, E50

\footnotetext{
* J. Scott Davis, Research Department, Federal Reserve Bank of Dallas, 2200 N. Pearl Street, Dallas, TX 75201. 214-922-5124. scott.davis@dal.frb.org. I would like to thank Alexander Chudik, Mark Wynne and seminar participants at the Federal Reserve Bank of Dallas for many helpful comments and suggestions. I would also like to thank Adrienne Mack and Peyton Odom for excellent research assistance. The views in this paper are those of the author and do not necessarily reflect the views of the Federal Reserve Bank of Dallas or the Federal Reserve System.
} 


\section{Introduction}

Milton Friedman said that "Inflation is always and everywhere a monetary phenomenon" (1968). Friedman was careful to qualify that inflation is a "steady and sustained rise in prices", for while a number of factors can lead to a transitory movement in prices in the short run, only monetary policy can cause a sustained rise in the price level over the medium to long run. Movements in current inflation could be driven by a number of factors unrelated to monetary policy, but the expectation of inflation over the long run should be entirely driven by their perception of monetary policy.

The benefit of setting a credible inflation target is that it anchors inflation expectations (Bernanke et al., 2001). If the central bank announces that it will keep inflation at $x \%$ over the medium to long run, and agents believe them, then the public's inflation expectations should be $x \%$.

Given the general lack of direct observations of inflation expectations for many countries, most empirical papers that test the effect of inflation targeting measure the effect of targeting on the level and variability of observed inflation. Here the evidence about the effectiveness of inflation targeting is mixed. Mishkin and Schmidt-Hebbel (2007) find that the adoption of inflation targeting in developed countries has led to a steeper drop in the level and variability of observed inflation than in similar countries that did not adopt inflation targeting. Gonçalves and Salles (2008) extend this analysis to a group of developing countries and find the opposite. They argue that, compared with other developing countries that did not adopt inflation targeting, inflation targeting countries have experienced significantly greater falls in both the level and volatility of inflation. Ball and Sheridan (2005) find the same results, but they argue that much of this is simply explained by a reversion to the mean. Brito and Bystedt (2010) argue with a panel data study that these benefits of inflation targeting in

developing countries wash out when one controls for a common time component. Similarly, Lin and Ye $(2007 ; 2009)$ argue that after accounting for self-selection using propensity score 
methods, the adoption of inflation targeting has no effect on either the level or volatility or observed inflation in both developed and developing countries.

Walsh (2007) and Crowe (2010) argue that the adoption of inflation targeting boosts the transparency of the central bank, and Crowe and Meade (2008) and Dincer and Eichengreen (2007; 2009; 2013) find empirical evidence that greater central bank transparency reduces both the level and the variability of observed inflation.

Since inflation expectations are incorporated into wage and price setting, which then affect the price level in the future, the unanchoring of inflation expectations is closely related to the persistence of observed inflation. Benati (2008) estimates inflation persistence in many different countries across many different monetary regimes. He finds that inflation persistence was near zero in many of the countries on the gold standard, while he cannot reject the hypothesis that in many developed countries inflation followed a random walk throughout much of the post-World War II period. He finds that in the post-Volcker United States, inflation does not follow a random walk but the persistence parameter is still positive and significant, while persistence is near zero in many inflation targeting countries.

Using more direct measures of inflation expectations from far forward Treasury yields, Gürkaynak et al. (2005) find that in the U.S., long-run inflation expectations respond to macroeconomic news. Long-forward rates, which they argue are mainly composed of inflation expectations, should not respond to macroeconomic news if inflation expectations are truly anchored. Gürkaynak et al. (2006) do a similar exercise but compare the response of farforward rates in the U.S., the UK, and Sweden to macroeconomic news. They find that far forward rates respond very little to news in inflation targeting Sweden and respond the most in the U.S. ${ }^{1}$ Their sample contains data from the UK from both before and after the independence of the Bank of England. They find that far forward rates from preindependence UK behave more like those from the U.S., but far forward rates from postindependence UK behave more like Sweden. Gürkaynak et al. (2007) find the same results

\footnotetext{
${ }^{1}$ The U.S. Federal Reserve adopted a numerical infaltion target in early 2012.
} 
when comparing the behavior of long-run inflation expectations in the United States with those from inflation targeting Canada and Chile. Similarly Beechey et al. (2011) use far forward inflation expectations derived from inflation swaps and find that far forward inflation expectations in the U.S. are more sensitive to current macroeconomic news than far-forward expectations in a number of inflation targeting European countries.

This paper will make use of survey data of one-year-ahead inflation expectations from Consensus Economics. ${ }^{2}$ The benefit of this dataset it that it allows us to directly measure the adoption of inflation targeting on the anchoring of inflation expectations using evidence from 36 countries. This paper will consider monthly data from 1990 to 2011 . Around the mid-point of this time period, 13 countries in the sample adopted inflation targeting, while 23 did not. With a structural VAR analysis, we compare the behavior of inflation expectations in the first and second halves of the sample period in both the group of 13 countries that adopted inflation targeting around the year 2000 and the control group of 23 countries that did not. The results from impulse responses and variance decompositions show that there was a significant decline in both the volatility and persistence of inflation expectations, as well as a significant reduction in the response of inflation expectations to a shock to either observed inflation or the price of oil between the early and late subperiods for the group of countries that adopted inflation targeting around the year 2000, but there was no difference between the early and late subperiods for the control group of 23 countries that did not. Thus the adoption of inflation targeting had a significant effect on the anchoring of inflation expectations in these 13 countries.

By incorporating direct measures of inflation expectations into a structural VAR, this paper can be seen as the international extension of Leduc et al. (2007), who incorporate oneyear-ahead inflation expectations from the Federal Reserve Bank of Philadelphia's Livingston survey into a structural VAR and show that there was a difference in the behavior of inflation

\footnotetext{
${ }^{2}$ Recently, a number of other papers, including Capistrán and Ramos-Francia (2010), Devereux et al. (2012), Berkmen et al. (2012), Wright (2011), have also made use of professional forecasting data from Consensus Economics.
} 
expectations in the United States between the pre- and post-1979 periods. They conclude that the change in U.S. monetary regime in 1979 with the Fed Chairmanship of Paul Volcker served to anchor U.S. inflation expectations. ${ }^{3}$ In extending this analysis to 36 countries this paper reaches a similar conclusion; the adoption of inflation targeting by many countries around the mid-point of our sample period was a similar monetary regime change that served to anchor inflation expectations between the first and the second halves of our sample period.

This paper will proceed as follows. Section 2 presents the structural VAR model used in this paper and discusses the variables and sources of data. The results of this structural VAR analysis are presented in section 3. First with impulse response diagrams and then with the results from variance decompositions, this paper will show that there was a major change in the behavior of inflation expectations between the first and second halves of the sample period for the 13 countries that adopted inflation targeting around the year 2000, but there was no change in the behavior of inflation expectations in the control group of 23 countries that did not. Section 4 discusses the robustness of these results to alternative identification schemes in the structural VAR, and to the exclusion of certain countries from the control group. Finally section 5 concludes with some directions for further research.

\section{$2 \quad$ Data and Econometric Model}

The benchmark model is a structural VAR of one-year-ahead expected inflation (EPi), observed inflation $(\mathrm{Pi})$, the output gap (OG), the change in the nominal price of oil (PO), and the nominal interest rate $(\mathrm{R})$ :

$$
\mathbf{Y}_{t}=\mathbf{A}(L) \mathbf{Y}_{t-1}+\mathbf{u}_{t}
$$

\footnotetext{
${ }^{3}$ See Clarida et al. (2002), Lubik and Schorfheide (2004), Boivin and Giannoni (2006), Stock and Watson (2007), Blanchard and Gali (2007), Blanchard and Riggi (2009), Mehra and Herrington (2008), Goodfriend and King (2005), Ireland (2007), Schorfheide (2005) and Del Negro and Eusepi (2012), Bianchi (2013), among others, for further evidence of a shift in U.S. monetary policy in about 1979.
} 
where $\mathbf{Y}_{t}$ is a $5 \times 1$ vector. Impulse responses and variance decompositions are generated with a recursive identification scheme with the ordering [EPi,Pi,OG,PO,R]. Expected inflation is ordered first since, as will be discussed later in this section, it is pre-determined by construction. In a later section we will test the robustness of the main results to alternative ordering schemes.

This VAR model is estimated to produce impulse responses for each country in the study in both the pre-2000 and post-2000 periods. The optimal lag length is chosen for each separate estimation based on SIC tests.

\subsection{Data}

The countries in the analysis are separated into four groups. Developed countries that adopted inflation targeting around the year 2000 (Group 1), emerging market countries that adopted inflation targeting around the year 2000 (Group 2), developed countries that did not adopt inflation targeting around the year 2000 (Group 3), and emerging market countries that did not adopt inflation targeting around the year 2000 (Group 4). The members of each group, and the year that each member of groups 1 or 2 adopted inflation targeting are listed in table 1.

Table 1: Countries included in this study.

\begin{tabular}{|c|c|c|c|}
\hline Group 1: & Group 2: & Group 3: & Group 4: \\
\hline Norway (2001) & Columbia (1999) & Canada & Argentina \\
\hline S. Korea (1998) & Slovakia (2005) & France & Bangladesh \\
\hline \multirow[t]{9}{*}{ Switzerland (2000) } & Romania (2005) & Germany & India \\
\hline & Brazil (1999) & Ireland & Malaysia \\
\hline & Hungary (2001) & Italy & Pakistan \\
\hline & Indonesia (2005) & Japan & Singapore \\
\hline & Mexico (1999) & Spain & Chile \\
\hline & Peru (2002) & Sweden & Slovenia \\
\hline & S. Africa (2000) & U.K. & Taiwan \\
\hline & Philippines (1998) & U.S. & Venezuela \\
\hline & & Finland & $\begin{array}{c}\text { Hong Kong } \\
\text { Uruguay }\end{array}$ \\
\hline
\end{tabular}


Notice that while groups 1 and 2 are made up of countries that adopted inflation targeting sometime around the year 2000, groups 3 and 4 are a control group and are made up of some countries that adopted inflation targeting much earlier (like Canada, 1991 or Chile, 1990) and other countries that never adopted inflation targeting. What distinguishes the countries in groups 3 and 4 and what sets them apart as a control group is simply the fact that they did not adopt inflation targeting around the mid-point of time period studied in this paper.

We will consider monthly data from 1990 to 2011. The first variable in the benchmark ordering is the expected inflation rate, EPi. This data is taken from the professional forecasting firm, Consensus Economics. The Consensus survey data is collected around the middle of the month. So for instance, the observation of EPi for a given country in July of a given year is collected around July 15th. Information about the observed inflation rate over the month $(\mathrm{Pi})$, and the output gap (OG) wouldn't be known until the data for July is released sometime in August. Likewise, the change in the price of oil (PO) and the average interest rate over the month (R) aren't known until the end of July. Thus the observation for expected inflation (EPi) is recorded long before the values of any contemporaneous variables are observed. ${ }^{4}$

The Consensus survey asks survey respondents for their forecast of observed inflation during this calendar year and the next calendar year. Thus the one-year-ahead expected inflation rate is not recorded. We use a simple weighted extrapolation to combine the inflation expectations over two calendar years into one measure of one-year-ahead inflation expectations, where the weight placed on the response for expected inflation in this calendar year is simply the number of months that are left in the year. So for instance, the oneyear-ahead expected inflation rate in March is a weighted average of the forecasts for this year and next year, where the weight on the forecast for this calendar year is $9 / 12$. The weight on the forecast for this calendar year for the one-year-ahead expected inflation rate in September is 4/12.

\footnotetext{
${ }^{4}$ More information about this data from Consensus Economics Inc. can be found at www.consensuseconomics.com/what_are_consensus_forecasts.htm.
} 
The other variables in the VAR are standard. The observed inflation rate is simply the year-over-year change in the headline consumer price index. The output gap is simply the percent deviation of industrial production from its HP filtered trend. The change in the nominal price of oil is simply the month-over-month change in the price of oil converted into local currency terms at the spot exchange rate. The interest rate is simply the rate on 3-month government bills.

The time series of one-year-ahead inflation expectations and observed inflation are presented in figures 1 and 2. Figure 1 plots the GDP weighted average of inflation expectations and observed inflation for the countries that adopted inflation targeting around the year 2000 (groups 1 and 2) and those that did not (groups 3 and 4). The data for most countries begins in 1990, but the data for some countries in the study do not begin until the mid-1990s.

The figure shows that both inflation expectations and observed inflation were relatively steady across this entire time period for counties in the control group. There is no noticeable difference in either the level or the dynamics of inflation expectations or observed inflation between the pre- and post-2000 periods in the solid blue line. This is in contrast to the countries that adopted inflation targeting around the mid-point of this sample, where inflation expectations and observed inflation were high and volatile in the first half of the sample period, but were steady and are similar to those in the control group during the second half of the sample period.

Figure 2 reports these same statistics, but here the time series from the developed countries in the study are presented separately from those for the emerging market countries. The top half of the figure plots the time series for inflation expectations and observed inflation for both the developed countries that adopted inflation targeting around the mid-point of the sample (group 1) and the developed countries that did not adopt inflation targeting around 2000 (group 3). The bottom half of the figure does the same for the emerging market countries in the study (groups 2 and 4).

Figure 2 shows that the same results seen earlier continue to hold when developed coun- 
tries are considered separately from emerging market countries. In both cases, there is a noticeable difference between the first and second half of the sample periods for the countries that adopted inflation targeting around the year 2000, and very little change between the two halves of the sample period in the countries that did not.

\section{Results}

To show how the adoption of inflation targeting has anchored inflation expectations and changed the behavior of both inflation expectations and observed inflation, we will present the results in two parts. In the first we will examine the responses of observed inflation and inflation expectations to a shock to either inflation expectations, observed inflation, or the price of oil. These impulse responses will be computed separately for both the pre-2000 and post-2000 periods, and we compare the difference between the pre- and post-2000 responses in the 13 countries that adopted inflation targeting around the year 2000 with the difference in the control group of 23 countries that did not. In the second part of this section we examine variance decompositions to identify what factors drove the fluctuations in inflation expectations in the pre- and post-2000 subperiods.

\subsection{Impulse responses}

Impulse responses are calculated in both the pre- and post-2000 subperiods in each of the 36 countries in this study. As discussed earlier, in the benchmark specification, shocks are identified with a recursive identification scheme with the ordering: expected inflation, observed inflation, the output gap, the change in the price of oil, and the short-term interest rate. In the next section we will instead consider the specification where expected inflation is ordered third, after observed inflation and the output gap.

Impulse responses are calculated for each of the 36 countries. However, to save space, this paper will only present the GDP weighted average of these responses across the different 
country groupings listed in table 1. In addition, this paper will only report the responses of inflation expectations and observed inflation to either a shock to inflation expectations, a shock to observed inflation, or a shock to the price of oil. ${ }^{5}$

These responses, for the 13 countries that adopted inflation targeting around the year 2000 (groups 1 and 2 in table 1) are presented in figure 3. The same impulse responses for the control group of 23 countries are presented in figure 4 .

Each figure presents the responses of inflation expectations and observed inflation following three shocks. The top row of diagrams presents the responses to a shock to expected inflation, the second row presents the responses to a shock to observed inflation, and the third row presents the responses to a shock to the month-over-month growth rate in the price of oil. Each diagram plots the response and one standard error confidence bands using the pre-2000 data in the dashed red line and using the post-2000 data with the solid blue line. ${ }^{6}$

Figure 3 shows that for the group of 13 countries that adopted inflation targeting around the year 2000, the responses to a shock are much greater and much more persistent in the pre-2000 data than in the post-2000 data. The diagrams in the top row of the figure show that the volatility of shocks to expected inflation were much smaller in the later subperiod, and they would quickly dissipate. The diagrams in the second and third rows of the figure show that in the early subperiod, a shock to either observed inflation or the price of oil would lead to a large and persistent increase in inflation expectations, but the shocks have little effect on inflation expectations in the post-2000 period.

\footnotetext{
${ }^{5}$ The results for any individual country, or the responses of the other variables in the model are available from the author on request.

${ }^{6}$ Of course the standard error for a weighted average impulse response is simply equal to the weighted average of standard errors of the individual impulse responses only when the error terms in the impulse responses are perfectly correlated across countries. If they are not, the standard error of the weighted average impulse response will be lower. Since the impulse responses for each country are estimated separately there is no way to calculate a standard error of the weighted average impulse response without estimating the crossdependence of individual impulse response estimates across countries. However, the goal of this exercise is to show that the weighted average impulse response in the earlier period lies well outside of the confidence range of the weighted average impulse response in the later period. By assuming that the standard error for the weighted average impulse response is simply equal to the weighted average of standard errors, we are assuming the highest value possible for this standard error.
} 
By contrast, figure 4 shows that in the control group there is very little difference between the pre- and post-2000 impulse responses. The top row of the figure shows that shocks to expected inflation are actually more volatile in the post-2000 data, and the persistence of inflation expectations is about the same in both subperiods. The diagrams in the second and third row of the figure show that the response of inflation expectations following a shock to either observed inflation or the price of oil was actually slightly greater in the post-2000 period, and the confidence bands show that the difference between the responses in the early and late subperiods in the control group of countries is not statistically significant.

Figures 5 and 6 repeat the same exercise, but only for the developed countries in the study (groups 1 and 3 in table 1). The top row of figure 5 shows that a shock to expected inflation is more persistent in the pre-2000 period than in the post-2000 period in the group of developed countries that adopted inflation targeting around the year 2000. The top row of figure 6 shows that there is not a statistically significant difference in the responses to a shock to expected inflation in the control group of countries. Furthermore, the second and third rows of figure 5 show that the response of expected inflation following a shock to either observed inflation or a shock to the price of oil is greater and much more persistent in the group of countries that adopted inflation targeting around 2000, but these same diagrams in figure 6 shows that there is not a statistically significant difference between the responses in the two subperiods in the control group developed countries.

Figures 7 and 8 repeat the same exercise, but for the emerging market countries in the study (groups 2 and 4 in table 1). The same results hold. Figure 7 shows that there is a significant difference in the volatility and persistence of expected inflation between the preand post-2000 periods in the group of countries that adopted inflation targeting, but there isn't a significant difference in the responses between the two subperiods in the control group of emerging market countries. 


\subsection{Variance decompositions}

To identify which shocks are responsible for the fluctuations in both expected inflation and observed inflation, variance decompositions are calculated in both the pre- and post-2000 subperiods in each of the 36 countries in this study. In the benchmark specification, shocks are identified with a recursive identification scheme with the ordering expected inflation, observed inflation, the output gap, the change in the price of oil, and the short-term interest rate. In the next section we will instead consider the specification where expected inflation is ordered third, after observed inflation and the output gap. These variance decompositions are calculated for each of the 36 countries. However, to save space, this paper will only present the GDP weighted average of these variance decompositions across the different country groupings listed in table $1 .{ }^{7}$

The decomposition of the variances of expected and observed inflation in both the group of 13 countries that adopted inflation targeting around the year 2000 and the control group of 23 countries that did not is presented in table 2 .

The results in the table present the forecast error variance of expected inflation and the share of that variance at the 12,24 , or 36 month horizon that can be explained by the five shocks in the model. The first column in the table shows that for the set of 13 countries that adopted infaltion targeting around the year 2000, there was a major drop in the forecast error variance of inflation expectations at all horizons. The variability of the forecast error fell from between $3-4 \%$ to around $1 \%$ between the pre- and post-2000 samples. Meanwhile in the control group of countries, there was almost no change between the two time periods.

The third column in the table reports the share of the forecast error variance that is due to shock to observed inflation. This describes the anchoring of inflation expectations. If a large part of the forecast error variance of expected inflation is attributable to shocks to observed inflation then inflation expectations are not well anchored. If this share falls between the early and the late subperiods, then inflation expectations are becoming better anchored.

\footnotetext{
${ }^{7}$ The results for any individual country are available from the author on request.
} 
The table shows that in the post-2000 subperiod, shocks to observed inflation explain about $11 \%$ of the variance of expected inflation in both groups of countries. However, in the pre2000 subperiod, shocks to observed inflation explain about $18 \%$ of the variance of expected inflation in the control group of countries, but they explain as much as $26 \%$ of the variance in expected inflation in the group of countries that did adopt inflation targeting around 2000. Thus the share of fluctuations in inflation expectations that are explained by shocks to observed inflation has fallen between the early and late subperiods for both groups of countries, but this share has fallen more in the group of countries that adopted inflation targeting around the year 2000. The anchoring of inflation expectations has improved in both groups of countries, but it has improved by more in the group of countries that adopted inflation targeting between the two subperiods.

These results continue to hold when we consider developed countries separately from emerging market countries. Table 3 presents this same decomposition of the forecast error variance of expected inflation in the pre- and post-2000 subperiods when developed countries and considered separately from emerging market countries. For the set of developed countries that adopted inflation targeting around the year 2000, the forecast error variance of expected inflation was nearly $0.8 \%$ in the pre-2000 period but around $0.6 \%$ in the post-2000 period. There was almost no change, indeed a slight increase in the forecast error variance of expected infaltion between the early and late subperiods in the control group of developed countries. Similarly, in the developed countries that adopted infaltion targeting around the year 2000, nearly $36 \%$ of the variance of expected inflation at a 12 month horizon was explained by shocks to observed inflation in the pre-targeting period, but only $13 \%$ or the variance of expected inflation is explained by the same shock in the post-targeting period. For the control group of developed countries, the fall in this share was only from $18 \%$ to $11 \%$. Thus within the subset of developed countries, there is strong evidence that the adoption of inflation targeting had a large effect on the anchoring of inflation expectations and significantly reduced the share of fluctuations in expected inflation that are explained by shocks in observed inflation. 
The results for the subset of emerging market counties are also presented in table 3 . Again we see a significant fall in the forecast error variance of expected infaltion between the early and late subperiods for the set of emerging market countries that adopted inflation targeting around the year 2000, from $5 \%$ to around $1 \%$, but there was no change in the forecast error variance of expected inflation in the control group of emerging market countries.

\section{Sensitivity Analysis}

To investigate the robustness of these results, we will first test the sensitivity of these results to an alternative recursive identification scheme where expected inflation in ordered after both observed inflation and the output gap. Then we will test the sensitivity of these results to different country groupings, namely if the results are robust to the exclusion of the Euro Area countries (which also saw a major monetary regime change around the year 2000).

\subsection{Re-ordering expected inflation}

In the previous section, shocks used to calculate impulse responses or variance decompositions are identified with a recursive identification scheme with the ordering: expected inflation, observed inflation, the output gap, the change in the price of oil, and the short-term interest rate. By construction, since the Consensus survey responses are collected before the data used to calculate the other variables in the model are known, expected inflation should not respond to contemporaneous shock to the other variables in the model. However, since observed inflation is calculated as year-over-year and the output gap is very persistent, one could argue that forecasters have a reasonable approximation for contemporaneous observed inflation and the output gap when completing the survey. In this case, a recursive identification scheme with the ordering: observed inflation, the output gap, expected inflation, the change in the price of oil, and the short-term interest rate might be more appropriate. The responses of expected inflation and observed inflation to a shock to either expected inflation, 
observed inflation, or the price of oil under this alternative identification scheme are presented in figure 9 and 10. Figure 9 presents the pre- and post-2000 responses for the group of countries that adopted inflation targeting around the year 2000, and figure 10 presents the responses for the control group of countries. The figures show that the responses are very similar under both the benchmark identification schedule and the alternative scheme. ${ }^{8}$

Similarly, the decomposition of the variance of expected inflation under the alternative ordering scheme is presented in table 4. The same results that were presented before under the benchmark identification scheme are even more dramatic here. The share of the variance of expected inflation at a 12 month horizon in the set of countries that adopted inflation targeting around the year 2000 is $44 \%$ in the pre-2000 period and $24 \%$ in the post-2000 period. The same shares in the early and late subperiods for the control group of countries is $22 \%$ and $20 \%$, respectively.

\subsection{Exclusion of the Euro Area countries}

The analysis so far has considered two groups of countries, those that adopted inflation targeting around the year 2000 and those that did not. The Euro Area countries in the sample: France, Germany, Ireland, Italy, Spain, Finland, and Slovenia, which are all included in the group of countries that did not adopt inflation targeting, also experienced a major monetary regime change around this time. Therefore to ensure that the adoption of the euro by so many countries in the control group is not clouding the results, we will reaggregate the impulse responses and variance decompositions and remove these seven euro area countries from the control group of countries that did not adopt inflation targeting.

The impulse responses for this new, ex-euro, control group are presented in figure 11. These impulse responses for the control group should be compared to those in figure 4 . The

\footnotetext{
${ }^{8}$ In fact, the impulse responses under the two ordering schemes look so similar that the easiest way to tell them apart is to notice that in the benchmark scheme, expected inflation is ordered before observed inflation, so in the second row of diagrams in figures 3 and 4, inflation expectations will not react to a contemporaneous shock to observed inflation. In the alternative scheme, observed inflation is ordered before expected inflation, so in figures 9 and 10 observed inflation will not react to a contemporaneous shock to expected inflation.
} 
impulse responses in the two figures are nearly identical, and thus the inclusion or exclusion of the euro area countries in the control group does not affect the results. The same holds true for the variance decomposition in table 5. The the decomposition of the variance of expected inflation in the ex-euro control group should be compared to the variance decomposition for the entire control group in table 2. Again, there is hardly any difference in the results, and thus the inclusion or the exclusion of the euro area countries in the control group doesn't affect the results.

\section{Summary and Conclusion}

By showing that there was a major change in the behavior of inflation expectations between the pre- and post-targeting subperiods for a number of countries that adopted inflation targeting around the year 2000, but there wasn't a similar change in the behavior of inflation expectations in the control group of countries, this paper shows that the adoption of inflation targeting has served to anchor inflation expectations in a number of developed and developing countries.

The natural next question to ask is why. What is it about inflation targeting that serves to anchor inflation expectations? Is that it changes the behavior and the reaction function of the central bank, or is it simply that the adoption of inflation targeting leads to greater transparency? When the public has better information about the true intentions and inflation fighting goals of the central bank they are less likely to change their expectations about future inflation following a transitory shock to observed inflation.

In the U.S. case, using 1979 as a break-point, Clarida et al. (2002), Boivin and Giannoni (2006), Ireland (2007), Lubik and Schorfheide (2004), Schorfheide (2005) all argue that the reason for the difference in the behavior of expected and observed inflation between preand post-1979 periods is that there was a significant change in the conduct of monetary policy or the central bank's reaction function occurring in 1979. However, this finding is 
called into doubt by Sims and Zha (2006). Andolfatto and Gomme (2003) Erceg and Levin (2003), Orphanides and Williams (2005; 2007) and Gaspar et al. (2006; 2011), Lansing (2009), Blanchard and Riggi (2009) present models where agents are uncertain about the credibility of the central bank. In this case, transitory shocks to observed inflation may be misinterpreted as a change in the central bank's long-term policy stance and thus shocks to observed inflation would have an outsized effect on fluctuations in the public's inflation expectations. Davis (2014) argues that the behavior of inflation expectations, particularly long-run inflation expectations in the post-Volcker United States can best be explained in a model where the Fed's monetary reaction function is unchanged but the central bank gradually regains credibility and with time is able to anchor inflation expectations by convincing the public of the Fed's commitment to a low and stable inflation rate.

Given that inflation targeting can be seen as both a change in the central bank's reaction function as well as a tool to enhance central bank transparency and credibility, an interesting direction for further research would be to dissect exactly how much of the anchoring of inflation expectations following the adoption of inflation targeting is due to an actual monetary regime shift and how much is simply due to better central bank credibility and communication. 


\section{References}

Andolfatto, D., Gomme, P., 2003. Monetary policy regimes and beliefs. International Economic Review 44, 1-30.

Ball, L. M., Sheridan, N., 2005. Does inflation targeting make a difference? In: Bernanke, B. S., Woodford, M. (Eds.), The Inflation-Targeting Debate. University of Chicago Press, pp. 249-282.

Beechey, M. J., Johannsen, B. K., Levin, A. T., 2011. Are long-run inflation expectations more firmly anchored in the euro-area than in the United States? American Economic Journal: Macroeconomics 3, 104-129.

Benati, L., 2008. Investigating inflation persistence across monetary regimes. Quarterly Journal of Economics 123 (3), 1005-1060.

Berkmen, S. P., Gelos, G., Rennhack, R., Walsh, J. P., 2012. The global financial crisis: Explaining cross-country differences in the output impact. Journal of International Money and Finance 31 (1), 32-59.

Bernanke, B. S., Laubach, T., Mishkin, F. S., 2001. Inflation targeting: lessons from the international experience. Princeton University Press, Princeton, NJ.

Bianchi, F., 2013. Regime switches, agentsS̆ beliefs, and post-world war II U.S. macroeconomic dynamics. Review of Economic Studies 80, 463-490.

Blanchard, O. J., Gali, J., September 2007. The macroeconomic effects of oil shocks: Why are the 2000s so different from the 1970s? NBER Working Paper no. 13368.

Blanchard, O. J., Riggi, M., October 2009. Why are the 2000s so different from the 1970s? a structural interpretation of changes in the macroeconomic effects of oil prices. NBER Working Paper no. 15467.

Boivin, J., Giannoni, M. P., 2006. Has monetary policy become more effective? Review of Economics and Statistics 88 (3), 445-462.

Brito, R. D., Bystedt, B., 2010. Inflation targeting in emerging economies, panel evidence. Journal of Development Economics 91, 198-210.

Capistrán, C., Ramos-Francia, M., 2010. Does inflation targeting affect the dispersion of inflation expectations? Journal of Money, Credit, and Banking 42 (1), 113-134.

Clarida, R., Gali, J., Gertler, M., 2002. A simple framework for monetary policy analysis. Journal of Monetary Economics 49, 879-904.

Crowe, C., 2010. Testing the transparency benefits of inflation targeting: Evidence from private sector forecasts. Journal of Monetary Economics 57, 226-232.

Crowe, C., Meade, E. M., 2008. Central bank independence and transparency: Evolution and effectiveness. IMF Working Paper no. 08/119. 
Davis, S., February 2014. Re-establishing credibility: The behavior of inflation expectations in the post-volcker united states. Federal Reserve Bank of Dallas, Globalization and Monetary Policy Institute Working Paper no. 171.

Del Negro, M., Eusepi, S., 2012. Fitting observed inflation expectations. Journal of Economic Dynamics and Control, forthcoming.

Devereux, M. B., Yetman, J., Smith, G. W., 2012. Consumption and real exchange rates in professional forecasts. Journal of International Economics 86, 33-42.

Dincer, N. N., Eichengreen, B., 2007. Central bank transparency: Where, why, and with what effects? NBER Working Paper No. 13003.

Dincer, N. N., Eichengreen, B., 2009. Central bank transparency: Causes, consequences and updates. mimeo.

Dincer, N. N., Eichengreen, B., 2013. Central bank transparency and independence: Updates and new measures. Bank of Korea Working Paper no. 2013-21.

Erceg, C. J., Levin, A. T., 2003. Imperfect credibility and inflation persistence. Journal of Monetary Economics 50, 915-944.

Friedman, M., 1968. Inflation: Causes and consequences. In: Dollars and Deficits: Living with America's Economic Problems. Prentice-Hall, Englewood Cliffs, NJ, pp. 21-71.

Gaspar, V., Smets, F., Vestin, D., 2006. Adaptive learning, persistence, and optimal monetary policy. Journal of the European Economic Association 4, 376-385.

Gaspar, V., Smets, F., Vestin, D., 2011. Inflation expectations, adaptive learning, and optimal monetary policy. In: Friedman, B. M., Woodford, M. (Eds.), Handbook of Monetary Economics. Vol. 3B. North Holland, pp. 1055-1096.

Gonçalves, C. E. S., Salles, J. M., 2008. Inflation targeting in emerging economies: What do the data say? Journal of Development Economics 85, 312-318.

Goodfriend, M., King, R. G., 2005. The incredible Volcker disinflation. Journal of Monetary Economics 52 (5), 981-1015.

Gürkaynak, R. S., Levin, A. T., Swanson, E. T., March 2006. Does inflation targeting anchor long-run inflation expectations? evidence from long-term bond yields in the u.s., u.k., and sweden. Tech. Rep. Federal Reserve Bank of San Francisco Working Paper no. 2006-09.

Gürkaynak, R. S., Marder, A. N., Levin, A. T., Swanson, E. T., 2007. Inflation targeting and the anchoring of inflation expectations in the western hemisphere. FRBSF Economic Review, 25-47.

Gürkaynak, R. S., Sack, B., Swanson, E. T., 2005. The sensitivity of long-term interest rates to economic news: Evidence and implications for macroeconomic models. American Economic Review 95 (1), 425-436. 
Ireland, P. N., 2007. Changes in the Federal Reserves's inflation target: Causes and consequences. Journal of Money, Credit, and Banking 39, 1851-1882.

Lansing, K. J., 2009. Time varying U.S. inflation dynamics and the New Keynesian Phillips curve. Review of Economic Dynamics 12 (2), 304-326.

Leduc, S., Sill, K., Stark, T., 2007. Self-fulfilling expectations and the inflation of the 1970s: Evidence from the Livingston Survey. Journal of Monetary Economics 54, 433-459.

Lin, S., Ye, H., 2007. Does inflation targeting really make a difference? evaluating the treatment effect of inflation targeting in seven industrial economies. Journal of Monetary Economics 54, 2521-2533.

Lin, S., Ye, H., 2009. Does inflation targeting make a difference in developing countries? Journal of Development Economics 89, 118-123.

Lubik, T., Schorfheide, F., 2004. Testing for indeterminacy: An application to u.s. monetary policy. American Economic Review 94 (1), 190-217.

Mehra, Y. P., Herrington, C., 2008. On the sources of movements in inflation expectations: A few insights from a VAR model. Federal Reserve Bank of Richmond Economic Quarterly $94(2), 121-146$.

Mishkin, F. S., Schmidt-Hebbel, K., 2007. Does inflation targeting make a difference? In: Mishkin, F. S., Schmidt-Hebbel, K., Loayza, N. (Eds.), Monetary Policy under Inflation Targeting. Central Bank of chile, pp. 291-372.

Orphanides, A., Williams, J. C., 2005. Imperfect knowledge, inflation expectations, and monetary policy. In: Bernanke, B. S., Woodford, M. (Eds.), The Inflation-Targeting Debate. University of Chicago Press, pp. 201-246.

Orphanides, A., Williams, J. C., 2007. Robust monetary policy with imperfect knowledge. Journal of Monetary Economics 54, 1406-1435.

Schorfheide, F., 2005. Learning and monetary policy shifts. Review of Economic Dynamics 8, 392-419.

Sims, C. A., Zha, T., 2006. Where there regime switches in u.s. monetary policy? American Economic Review 96 (1), 54-80.

Stock, J. H., Watson, M. W., 2007. Why has U.S. inflation become harder to forecast? Journal of Money, Credit, and Banking 39 (1), 3-33.

Walsh, C. E., 2007. Transparency, flexibility, and inflation targeting. In: Mishkin, F. S., Schmidt-Hebbel, K., Loayza, N. (Eds.), Monetary Policy under Inflation Targeting. Central Bank of chile, pp. 227-263.

Wright, J. H., 2011. Term premia and inflation uncertainty: Empirical evidence from an international panel dataset. American Economic Review 101 (4), 1514-1534. 

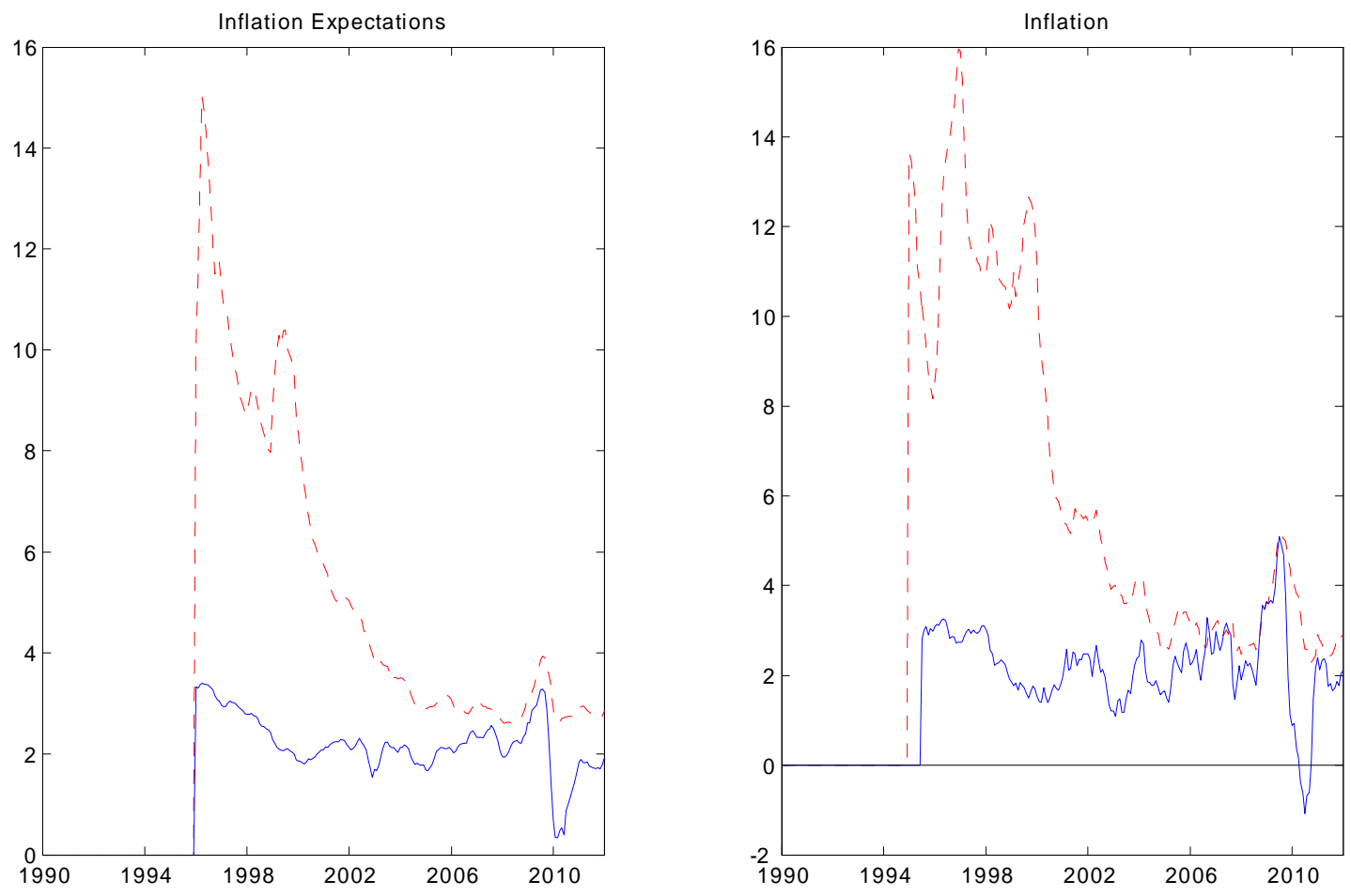

Figure 1: Inflation expectations and observed inflation for the two groups of countries. Countries that adopted inflation targeting around the year 2000 are presented in red. The countries did not are presented in blue. Inflation expectations data is from Consensus Economics Inc. 

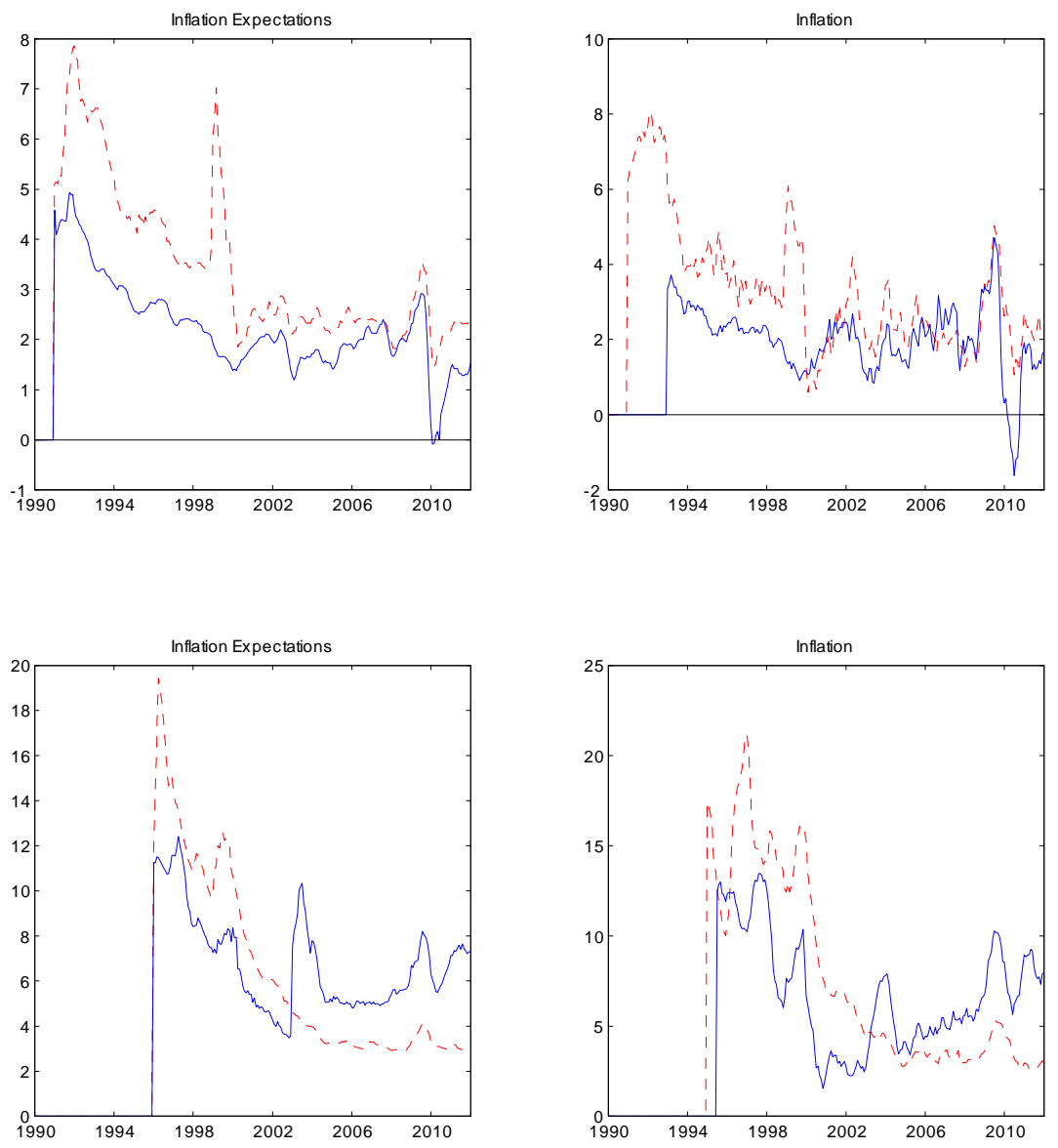

Figure 2: Inflation expectations and observed inflation for the two groups of countries. Countries that adopted inflation targeting around the year 2000 are presented in red. The countries did not are presented in blue. Inflation expectations data is from Consensus Economics Inc. Plots for developed countries are presented in the top row and developing countries are in the bottom row. 

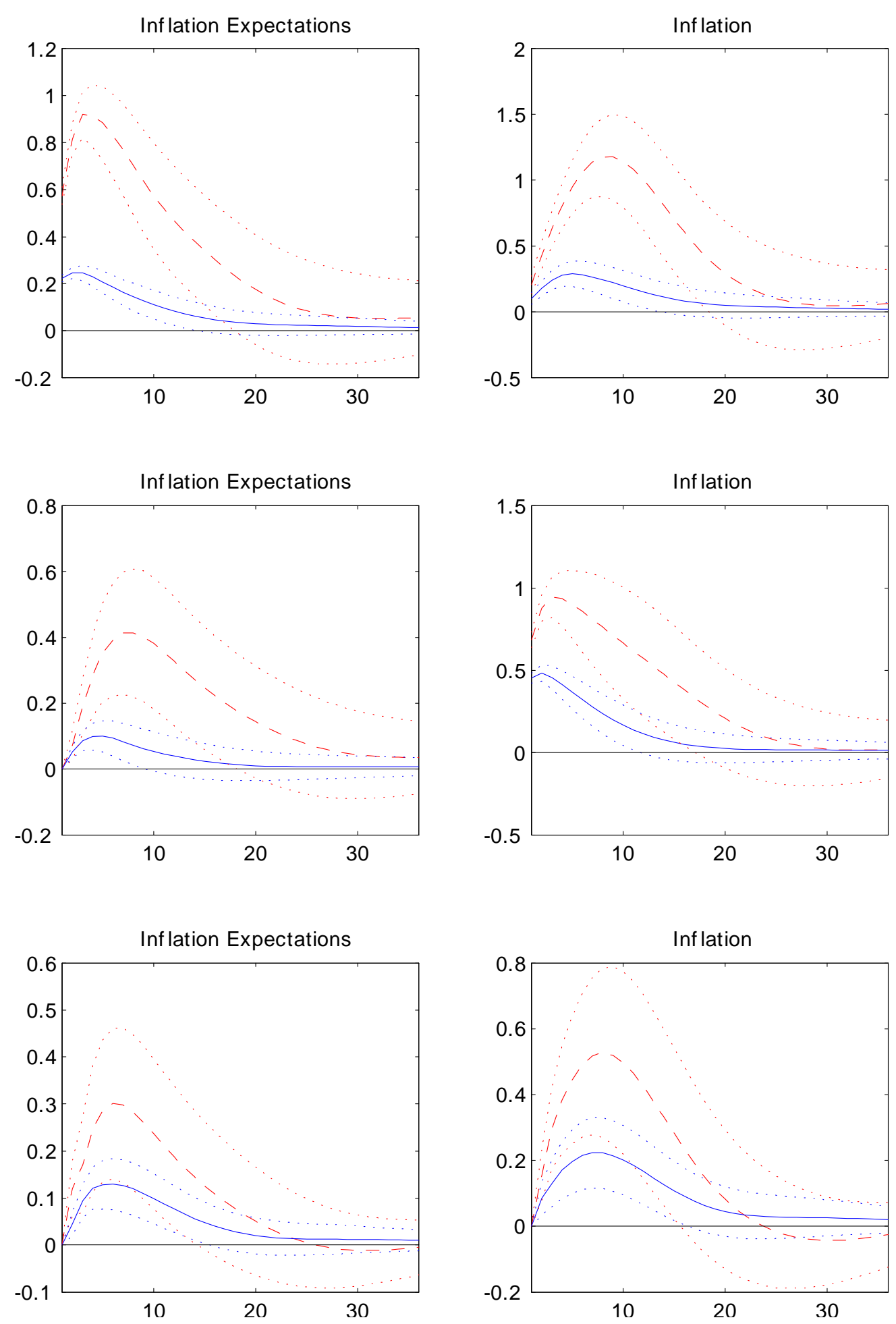

Figure 3: Impulse responses in countries that adopted inflation targeting around the year 2000. Responses in the pre-2000 data are in red, responses from the post-2000 data are in blue. Diagrams on the top row are responses following a one S.D. shock to inflation expectations, the second row are responses following a one S.D. shock to observed inflation, and the third row presents responses to a one S.D. shock to the price of oil. Dotted lines denote one S.E. bands. 

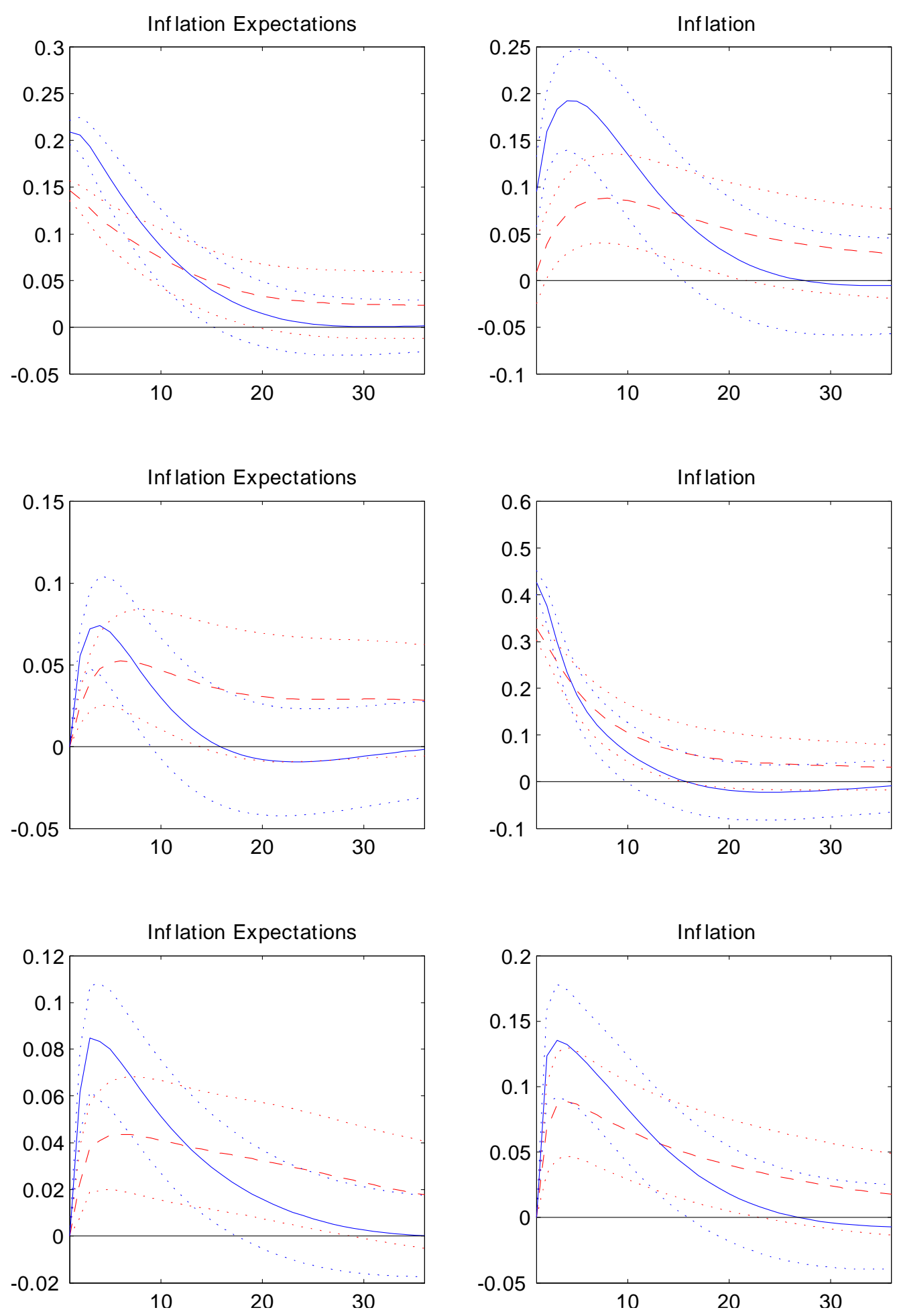

Figure 4: Impulse responses in countries that did not inflation targeting around the year 2000. Responses in the pre-2000 data are in red, responses from the post-2000 data are in blue. Diagrams on the top row are responses following a one S.D. shock to inflation expectations, the second row are responses following a one S.D. shock to observed inflation, and the third row presents responses to a one S.D. shock to the price of oil. Dotted lines denote one S.E. bands. 

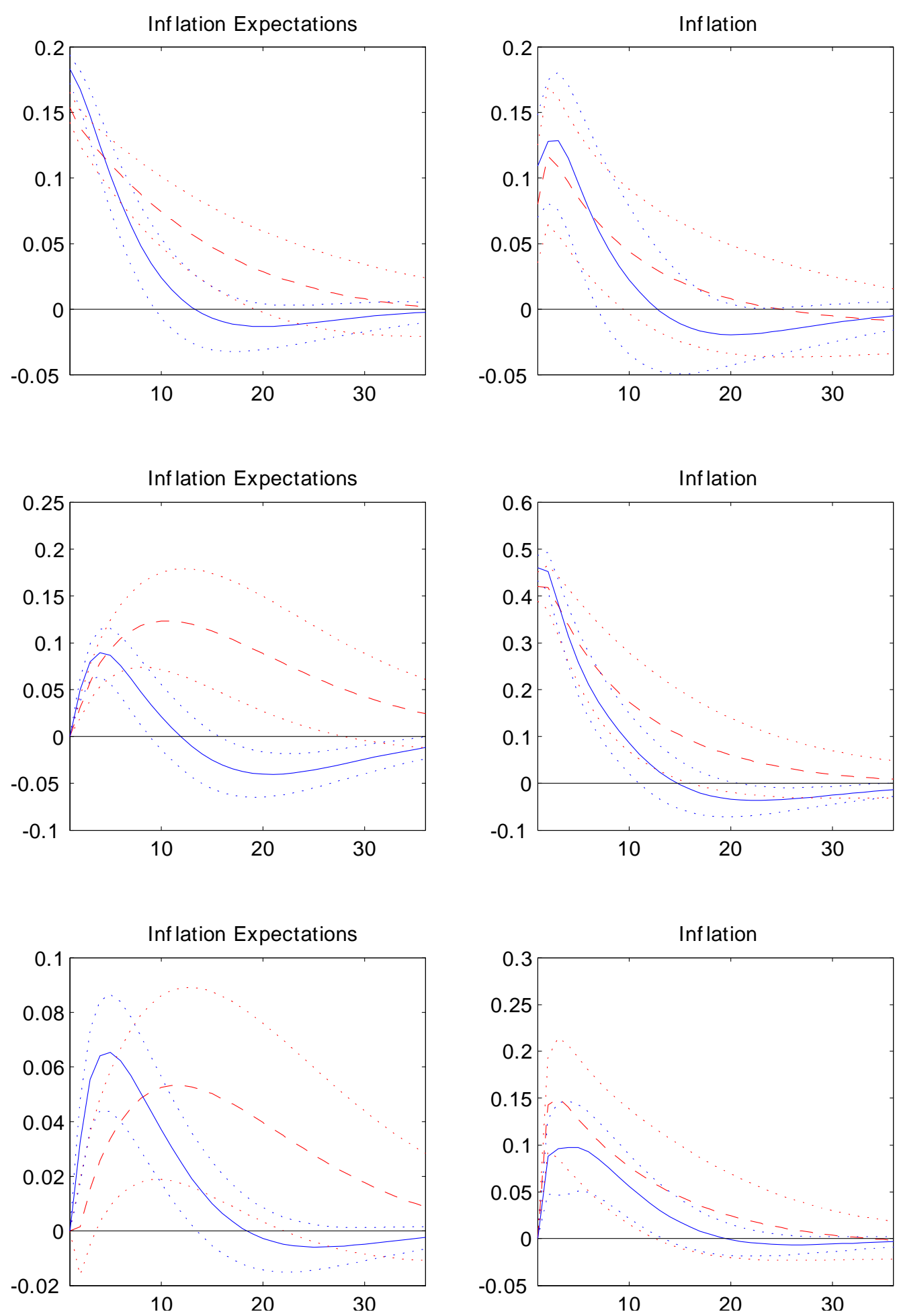

Figure 5: Impulse responses in developed countries that adopted inflation targeting around the year 2000. Responses in the pre-2000 data are in red, responses from the post-2000 data are in blue. Diagrams on the top row are responses following a one S.D. shock to inflation expectations, the second row are responses following a one S.D. shock to observed inflation, and the third row presents responses to a one S.D. shock to the price of oil. Dotted lines denote one S.E. bands. 

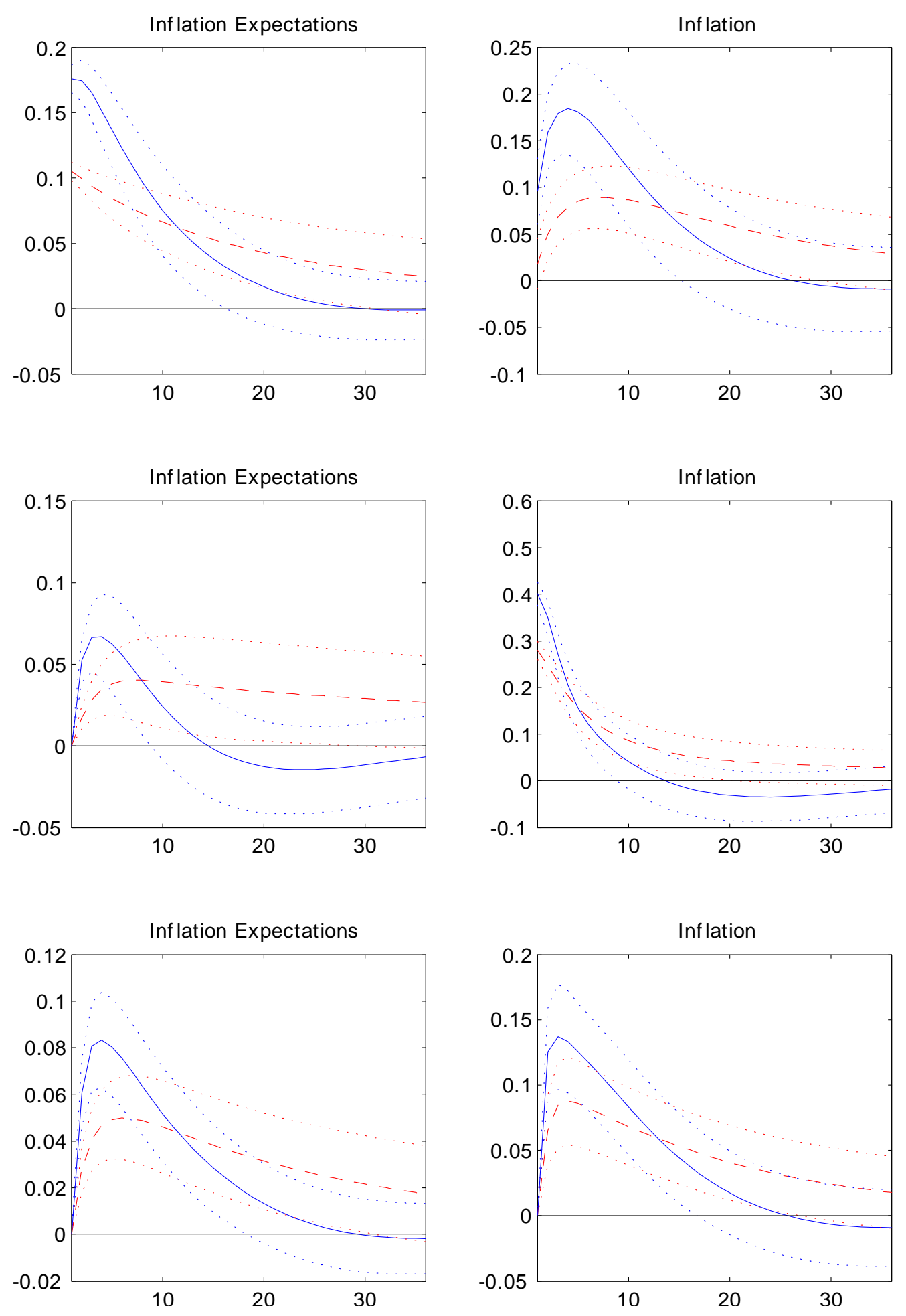

Figure 6: Impulse responses in developed countries that did not adopt inflation targeting around the year 2000. Responses in the pre-2000 data are in red, responses from the post2000 data are in blue. Diagrams on the top row are responses following a one S.D. shock to inflation expectations, the second row are responses following a one S.D. shock to observed inflation, and the third row presents responses to a one S.D. shock to the price of oil. Dotted lines denote one S.E. bands. 

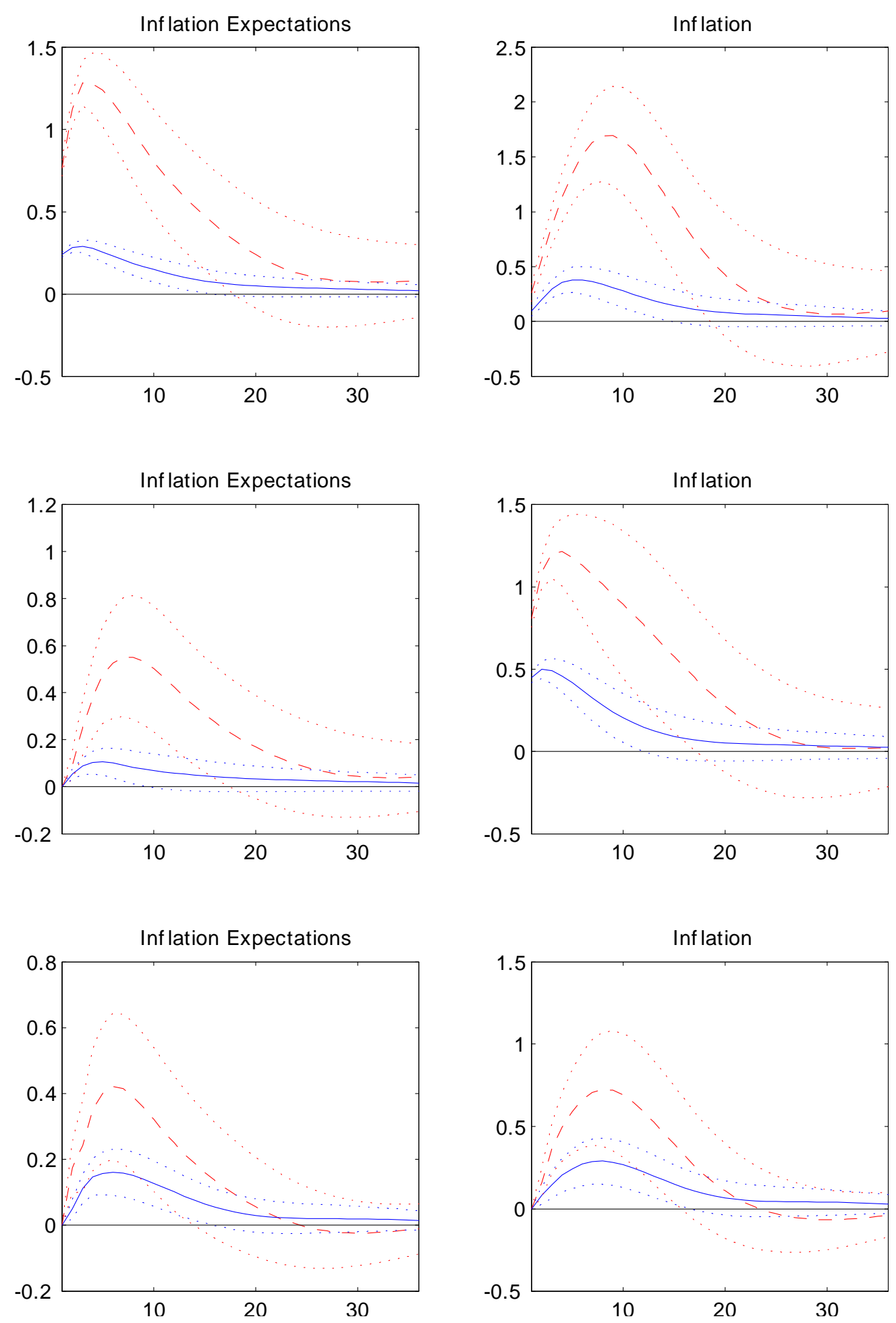

Figure 7: Impulse responses in developing countries that adopted inflation targeting around the year 2000. Responses in the pre-2000 data are in red, responses from the post-2000 data are in blue. Diagrams on the top row are responses following a one S.D. shock to inflation expectations, the second row are responses following a one S.D. shock to observed inflation, and the third row presents responses to a one S.D. shock to the price of oil. Dotted lines denote one S.E. bands. 

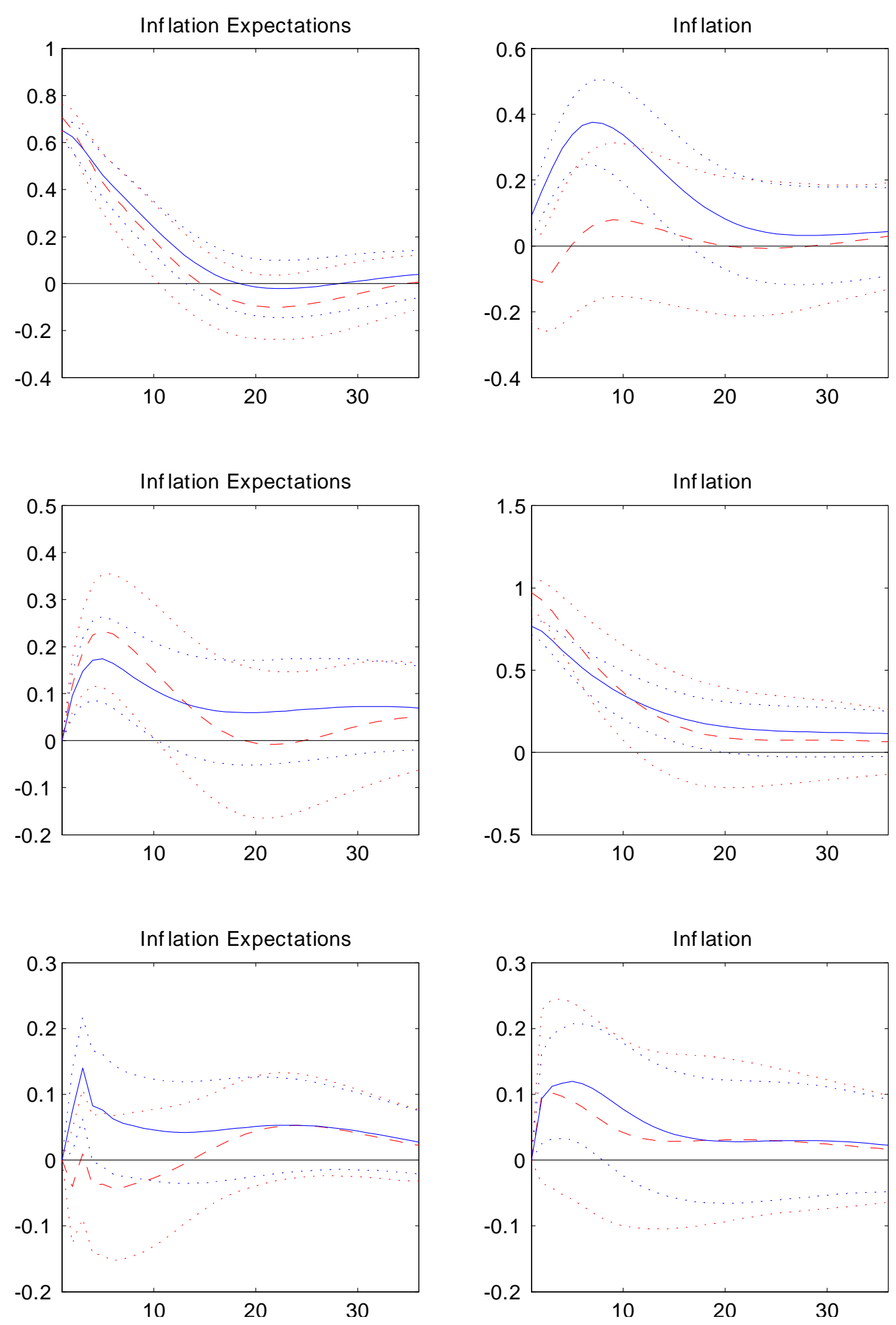

Figure 8: Impulse responses in developing countries that did not adopt inflation targeting around the year 2000. Responses in the pre-2000 data are in red, responses from the post2000 data are in blue. Diagrams on the top row are responses following a one S.D. shock to inflation expectations, the second row are responses following a one S.D. shock to observed inflation, and the third row presents responses to a one S.D. shock to the price of oil. Dotted lines denote one S.E. bands. 

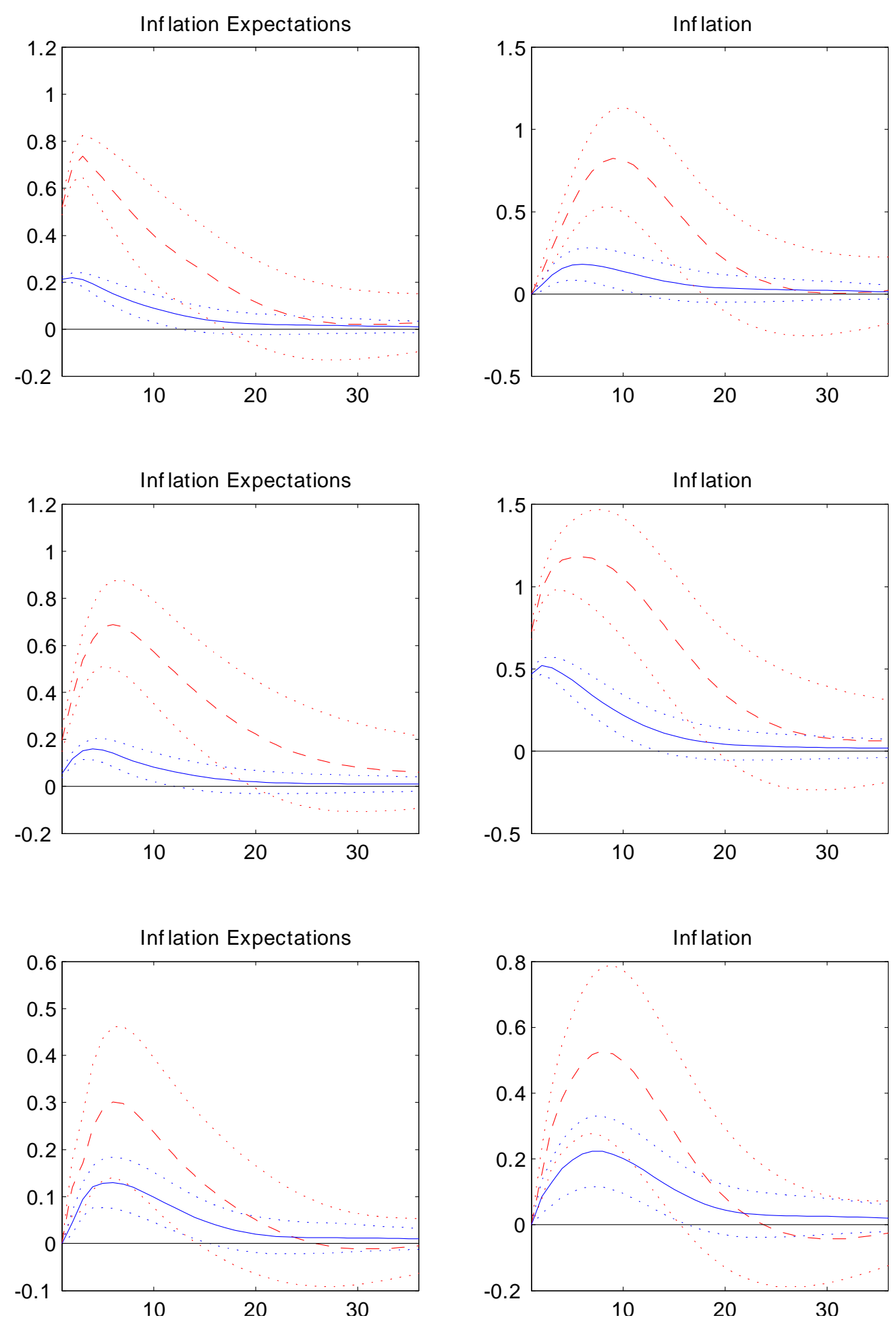

Figure 9: Impulse responses in countries that adopted inflation targeting around the year 2000. Responses in the pre-2000 data are in red, responses from the post-2000 data are in blue. Diagrams on the top row are responses following a one S.D. shock to inflation expectations, the second row are responses following a one S.D. shock to observed inflation, and the third row presents responses to a one S.D. shock to the price of oil. Dotted lines denote one S.E. bands. Using the alternative ordering. 

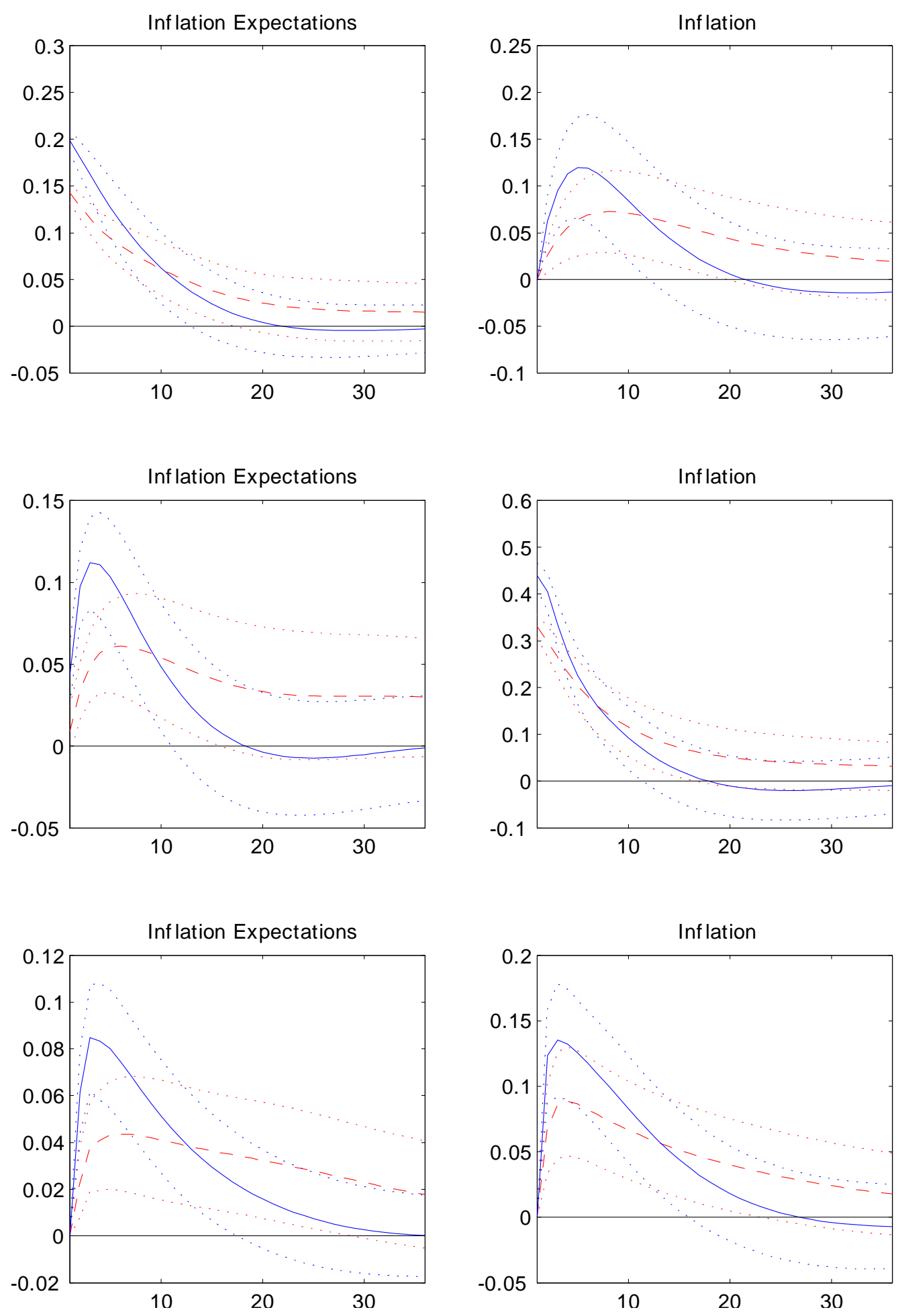

Figure 10: Impulse responses in countries that did not adopt inflation targeting around the year 2000. Responses in the pre-2000 data are in red, responses from the post-2000 data are in blue. Diagrams on the top row are responses following a one S.D. shock to inflation expectations, the second row are responses following a one S.D. shock to observed inflation, and the third row presents responses to a one S.D. shock to the price of oil. Dotted lines denote one S.E. bands. Using the alternative ordering. 

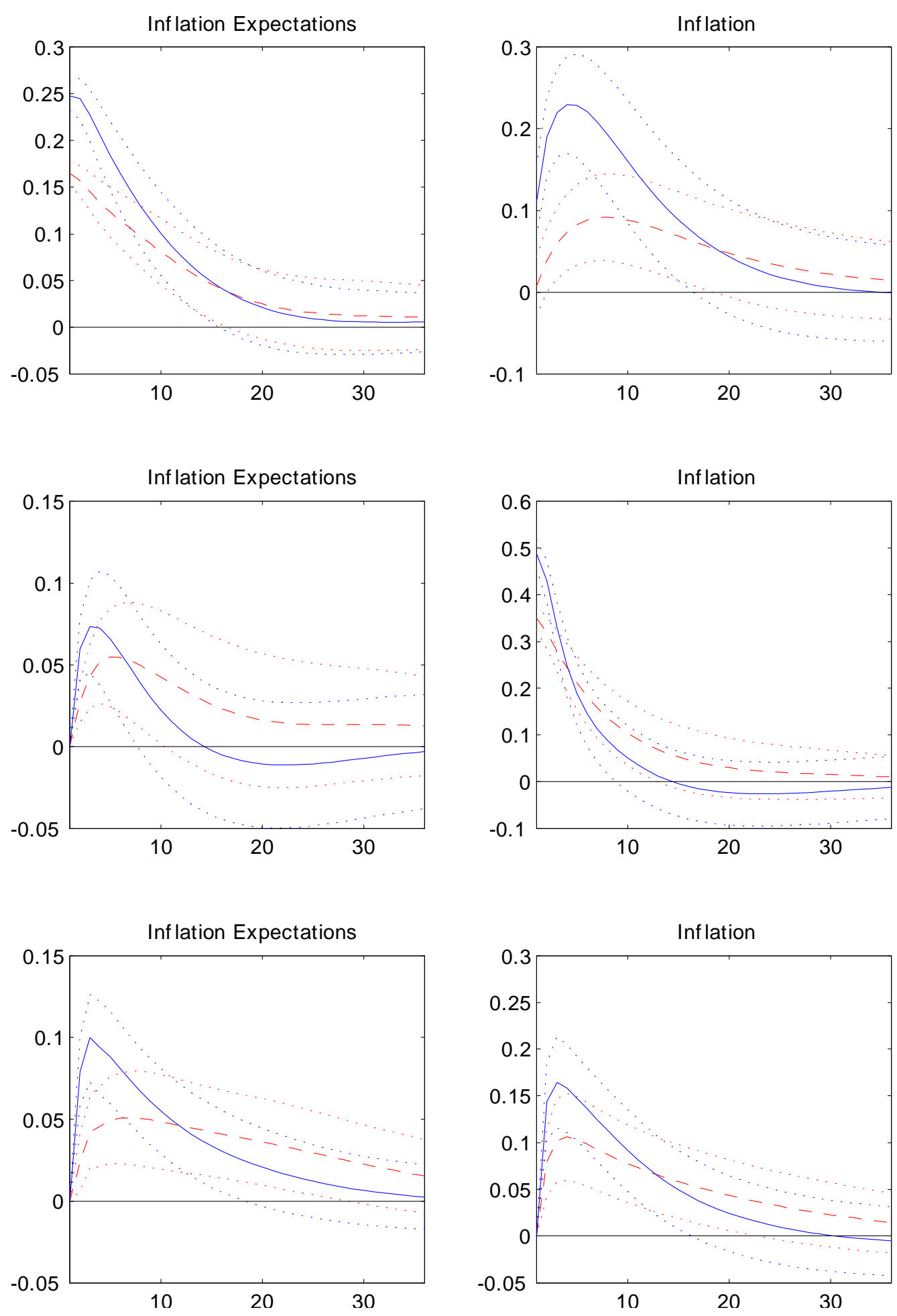

Figure 11: Impulse responses in countries that did not adopt inflation targeting around the year 2000. Responses in the pre-2000 data are in red, responses from the post-2000 data are in blue. Diagrams on the top row are responses following a one S.D. shock to inflation expectations, the second row are responses following a one S.D. shock to observed inflation, and the third row presents responses to a one S.D. shock to the price of oil. Dotted lines denote one S.E. bands. Excluding all Euro Area countries. 
Table 2: Variance decomposition of inflation expectations. Average across all countries.

\begin{tabular}{|c|c|c|c|c|c|c|}
\hline \multicolumn{7}{|c|}{ Countries that adopted inflation targeting around 2000} \\
\hline & FEV & Inf Ex & $\operatorname{Inf}$ & $\mathrm{OG}$ & Oil & $\mathrm{R}$ \\
\hline \multicolumn{7}{|l|}{ Pre-2000 } \\
\hline 1 year & 3.21 & 58.63 & 25.64 & 3.44 & 6.50 & 5.79 \\
\hline 2 year & 3.64 & 49.95 & 29.85 & 7.00 & 6.90 & 6.30 \\
\hline 3 year & 3.77 & 47.38 & 30.37 & 9.06 & 6.92 & 6.27 \\
\hline \multicolumn{7}{|l|}{ Post-2000 } \\
\hline 1 year & 0.91 & 57.01 & 11.31 & 10.36 & 12.50 & 8.81 \\
\hline 2 year & 0.99 & 52.11 & 13.22 & 10.83 & 12.49 & 11.35 \\
\hline 3 year & 1.01 & 50.60 & 14.17 & 10.67 & 12.47 & 12.10 \\
\hline \multicolumn{7}{|c|}{ Countries that did not adopt inflation targeting around 2000} \\
\hline & FEV & Inf Ex & Inf & $\mathrm{OG}$ & Oil & $\mathrm{R}$ \\
\hline \multicolumn{7}{|l|}{ Pre-2000 } \\
\hline 1 year & 0.54 & 47.44 & 18.43 & 14.04 & 15.73 & 4.36 \\
\hline 2 year & 0.70 & 37.63 & 20.61 & 19.06 & 16.20 & 6.50 \\
\hline 3 year & 0.78 & 34.39 & 21.04 & 20.52 & 16.00 & 8.04 \\
\hline \multicolumn{7}{|c|}{ Post-2000 } \\
\hline 1 year & 0.67 & 58.09 & 10.96 & 13.13 & 14.36 & 3.46 \\
\hline 2 year & 0.76 & 51.10 & 11.48 & 19.80 & 13.28 & 4.34 \\
\hline 3 year & 0.80 & 48.11 & 11.95 & 22.18 & 12.69 & 5.08 \\
\hline
\end{tabular}

Notes: FEV stands for Forecast Error variance 


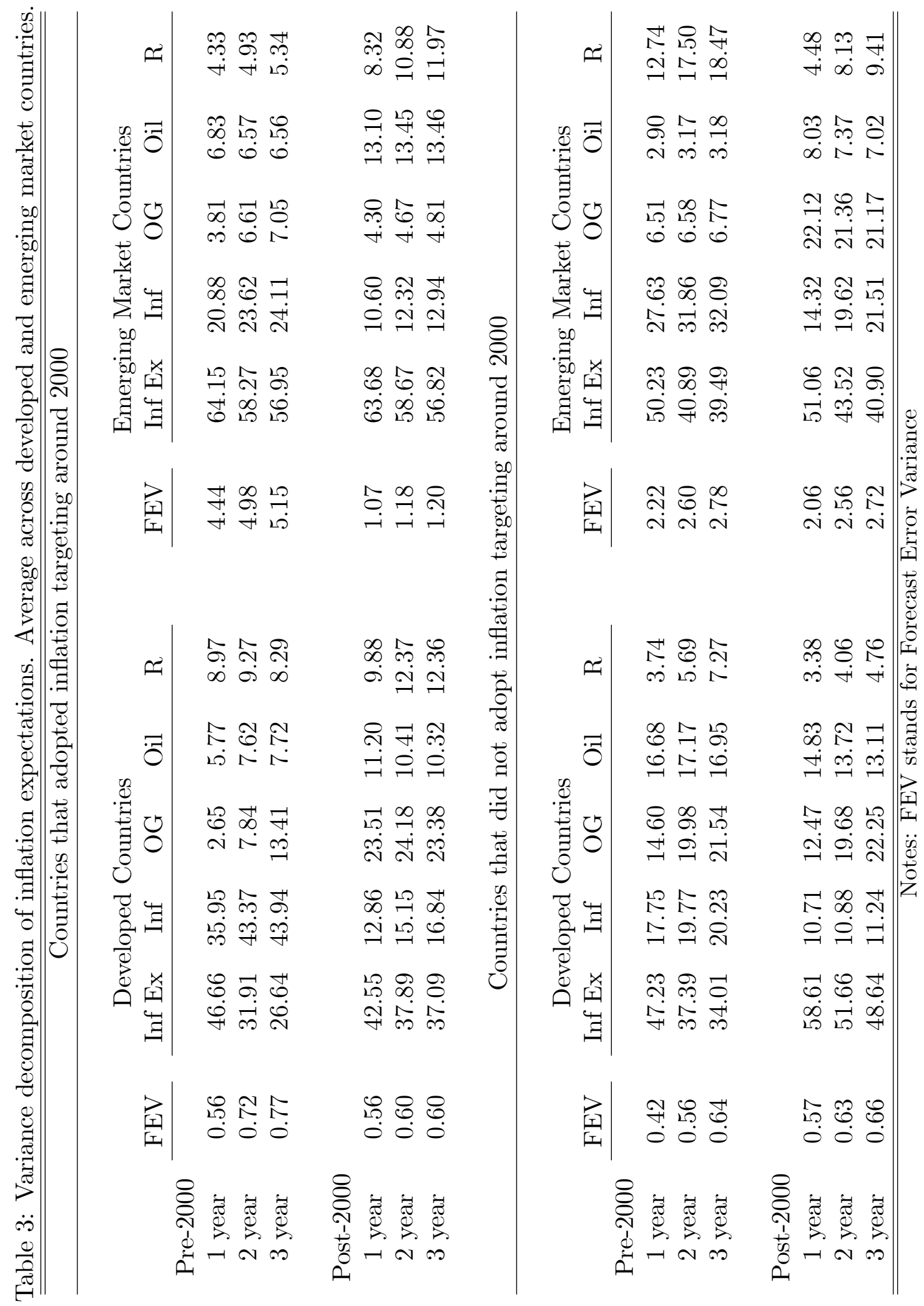


Table 4: Variance decomposition of inflation expectations. Average across all countries, Using the alternative ordering.

\begin{tabular}{|c|c|c|c|c|c|c|}
\hline \multicolumn{7}{|c|}{ Countries that adopted inflation targeting around 2000} \\
\hline & FEV & Inf Ex & $\operatorname{Inf}$ & OG & Oil & $\mathrm{R}$ \\
\hline \multicolumn{7}{|l|}{ Pre-2000 } \\
\hline 1 year & 3.21 & 38.35 & 44.30 & 5.05 & 6.50 & 5.79 \\
\hline 2 year & 3.64 & 31.12 & 47.42 & 8.26 & 6.90 & 6.30 \\
\hline 3 year & 3.77 & 28.96 & 47.59 & 10.26 & 6.92 & 6.27 \\
\hline \multicolumn{7}{|l|}{ Post-2000 } \\
\hline 1 year & 0.91 & 42.87 & 24.11 & 11.70 & 12.50 & 8.81 \\
\hline 2 year & 0.99 & 38.51 & 25.60 & 12.05 & 12.49 & 11.35 \\
\hline 3 year & 1.01 & 37.22 & 26.37 & 11.85 & 12.47 & 12.10 \\
\hline \multicolumn{7}{|c|}{ Countries that did not adopt inflation targeting around 2000} \\
\hline & FEV & Inf Ex & Inf & $\mathrm{OG}$ & Oil & $\mathrm{R}$ \\
\hline \multicolumn{7}{|l|}{ Pre-2000 } \\
\hline 1 year & 0.54 & 37.74 & 22.63 & 19.53 & 15.73 & 4.36 \\
\hline 2 year & 0.70 & 28.71 & 24.40 & 24.18 & 16.20 & 6.50 \\
\hline 3 year & 0.78 & 25.97 & 24.66 & 25.33 & 16.00 & 8.04 \\
\hline \multicolumn{7}{|l|}{ Post-2000 } \\
\hline 1 year & 0.67 & 40.16 & 20.94 & 21.08 & 14.36 & 3.46 \\
\hline 2 year & 0.76 & 34.86 & 19.88 & 27.65 & 13.28 & 4.34 \\
\hline 3 year & 0.80 & 32.78 & 19.64 & 29.82 & 12.69 & 5.08 \\
\hline
\end{tabular}

Notes: FEV stands for Forecast Error variance 
Table 5: Variance decomposition of inflation expectations.

\begin{tabular}{|c|c|c|c|c|c|c|}
\hline \multicolumn{7}{|c|}{ Excluding Euro Area Countries } \\
\hline & FEV & Inf Ex & Inf & OG & Oil & $\mathrm{R}$ \\
\hline Pre-2000 & & & & & & \\
\hline 1 year & 0.61 & 46.18 & 16.66 & 13.66 & 19.86 & 3.63 \\
\hline 2 year & 0.75 & 37.30 & 16.64 & 17.99 & 20.77 & 7.31 \\
\hline 3 year & 0.80 & 34.19 & 16.15 & 19.29 & 20.54 & 9.82 \\
\hline Post-2000 & & & & & & \\
\hline 1 year & 0.75 & 64.53 & 6.67 & 12.16 & 15.16 & 1.49 \\
\hline 2 year & 0.86 & 56.44 & 7.37 & 19.74 & 13.86 & 2.59 \\
\hline 3 year & 0.90 & 52.77 & 8.14 & 22.96 & 13.13 & 3.00 \\
\hline
\end{tabular}

